\title{
New Feminist Perspectives on the History of the Twentieth Century
}

\author{
Review essay by Melissa Feinberg
}

Maria Bucur, Gendering Modernism: A Historical Reappraisal of the Canon, London: Bloomsbury Academic, 2017, xi + 149 pp., \$24.95 (paperback), ISBN: 978-1-3500-2625-4.

Maria Bucur, The Century of Women: How Women Have Transformed the World Since 1900, Lanham, MD: Rowman and Littlefield, 2018, x + 232 pp., \$35.00 (paperback), ISBN: 978-1-4422-5739-9.

For many women's and gender historians, the ultimate goal of their work is to fundamentally change the way we think about the past. These historians do not want simply to add women to existing narratives; they want to rewrite them to account for the realities of women's lives as well as men's. Yet, despite all the excellent work that has been done by women's and gender historians over the past few decades, those established narratives have proved quite resistant to change. General history surveys, whether of a country, a continent, or the world, are almost invariably structured around the actions of male elites. Women may be present in these histories, but women's actions and women's concerns are rarely what drives the narrative. These two books by historian Maria Bucur are both attempts to write a different kind of general history that puts gender at the center of the story rather than at its margins.

Gendering Modernism argues that considering gender changes the way we should think about the modernist movement of the late nineteenth and early twentieth centuries. Modernist artists and thinkers from this period claimed they were revolutionaries who wanted to break decisively with traditions of all kinds. To what extent, Bucur asks, did their activities include a rebellion against traditional gender norms? This is not a question most historians of modernism have found important. Yet, Bucur suggests, it is impossible to evaluate modernists' claims about their own radicalism without considering their attitudes toward gender roles and family structures. Bucur's goal in this short volume is not to write a comprehensive survey of the ways modernists engaged (or did not engage) with gender. Instead, she provides an illustrative sketch 
of this terrain. She paints a nuanced and complicated landscape that encompasses the diversity of modernism. Modernism emerges from Bucur's gloss as shot through with masculinist prejudices, but nonetheless offering the space and possibility for some to imagine a different future for both sexes. Some well-known modernists, like writers Henrik Ibsen and Virginia Woolf, quite famously questioned patriarchy and even, in the case of Woolf, gender itself. Many others, however, quite comfortably married their radical views to gender traditionalism. As Bucur reminds us, Sigmund Freud's ideas about the formation of the personality were based on a normative masculine (women just envied men for the penis they lacked). Even the lesbian Gertrude Stein in large measure adhered to the gender norms of the day. Stein fashioned herself as a man and set a pattern of traditionally gendered behavior at her well-known salon; male guests conversed with Stein, while their wives were sent to another room to chat with Stein's partner, Alice B. Toklas.

Historians of modernism have created a canon of its most important figures that is largely male. Bucur argues that one element of the history of this canon is how the social circumstances of the time conspired to prevent many women from joining it. Women, for example, were largely excluded from attending fine art academies, making it difficult to learn the mechanics of painting and sculpture. Even in the realm of craft and design, which was more open to women, they faced discrimination. Clara Driscoll, who designed some of the most famous Tiffany lamps, was notably not credited by name, and was fired from the company after she married. In addition, women's crucial role in promoting, exhibiting, and financially supporting male modernist artists has often been neglected. As Bucur notes, it was women who donated most of the money to put on the 1913 Armory Show that introduced many modernist artists to the United States, and also women who were responsible for founding the Museum of Modern Art and the Whitney Museum in New York. Most general histories of modernism do not see these achievements as particularly significant.

Another question Bucur asks in the book is how the established canon of modernists would change if a revolutionary attitude toward gender norms was part of how we defined modernism. This requires seeing modernism as linked to radical social and political transformation, rather than focusing solely on cultural and intellectual production. Expanding the definition of modernism in this way allows Bucur to survey a wide array of early twentieth-century movements that advocated new experimentation in gender roles and sexual identities, including militant suffragism, sexology, eugenics, nudism, anarchism, communism, and fascism. As the very list suggests, Bucur is quite aware that radical views are not necessarily progressive ones. But, by putting together these very different groups and individuals, she is able to paint a picture of a moment of ferment where gender is very much at the center.

Gendering Modernism deals largely with Europe and North America from the 1890s through the 1930s. In The Century of Women, Bucur takes on a much larger canvas: the history of the world from 1900 to the present. This book is an attempt to think outside the usual signposts of historical narratives such as wars, revolutions, and regime changes. Instead of the actions of elites and states, Bucur highlights the fundamental social and cultural changes that have profoundly altered both women's and men's lives over the course of the last 120 years and emphasizes the role of women in shap- 
ing the contemporary world. This is a book that is unabashedly feminist and also unreservedly optimistic. Bucur argues that the twentieth century was a time in which gender norms all over the world underwent substantial change in large part due to the efforts of women themselves and that this transformation improved women's lives enormously.

The book is organized thematically rather than chronologically, although within each chapter the organization is roughly chronological. Individual chapters take up prominent topics in the transformation of women's lives: politics, population, economics, knowledge creation, culture, and kinship. The approach is global rather than comparative; Bucur does not attempt to cover all regions of the world when approaching each subject, but across the book as a whole she makes an effort to include examples from all over the globe.

Bucur is careful to draw out the nuances in her history even though her overall emphasis is on the progress women have made. For example, in the chapter on economics she details women's long fight to gain legal control over their own property and the enormous increase in the numbers of women in the wage-earning workforce, showing how many women around the world gradually came to enjoy economic independence while also noting that women have not yet reached economic parity with men in any part of the world or under any political system. She also is careful to describe how the economic advances women have made during the twentieth and twenty-first centuries have been unevenly distributed by race, class, and region. The work of childcare and family maintenance has remained undervalued and largely feminized. The ability of some women to develop white collar professional careers has largely depended upon the availability of poor women of color to take over the poorly remunerated work of caring for their families.

Bucur's deviation from most narratives of the twentieth century comes into sharp focus in the chapter on population. For many historians working on that century, the subject of population would be a topic framed by state violence, whether war, genocide, or other forms of biopolitics. In contrast, Bucur tells a story of women around the world beginning to learn about and take charge of their own sexuality and fertility. For many women, particularly in Europe and North America, pregnancy and even marriage itself became a choice rather than a destiny. Throughout the chapter, Bucur emphasizes women's own actions over state policies as the primary driver of demographic trends, stressing in particular the role of education and the spread of literacy in giving women the tools to control their fertility in whatever way they might choose.

Perhaps the most unexpected chapter is the one on knowledge production. At first glance, a reader might wonder why this chapter was included. The topic of women's entry into academia seems narrow compared with the enormous breadth and scope of the other chapters. The fact that women went from receiving 6 percent of the PhDs granted in the United States in 1900 to parity with men by 2010 is surely significant, but can it really compare with the equally dramatic shift in the number of double wage-earner households in the world in terms of global impact? Bucur argues that, indeed, it can. Women's entry into the realm of knowledge production, she claims, was (and is) a necessary precondition for more radical change. Even if women academics were not explicitly feminist, they brought different interests, backgrounds, concerns, 
and questions to their work. The result of all of their research has been that all of us have begun to think about the world a little differently.

As I read this book, I found myself wondering about its intended audience. It seems designed for undergraduate students, but there is no obvious course (at least in US colleges and universities) that this book fits. Most US courses in twentieth-century world history are organized chronologically, not thematically, and emphasize political rather than social and culture change. I can also well imagine the resistance any instructor would get to using a book called The Century of Women as the primary text in a course that was not specifically devoted to women's or gender history. The course evaluations would undoubtedly be full of comments exhorting the instructor to teach "real" history, with lots of World War I and World War II and some Cold War thrown in for good measure. But then, I thought, particularly by including the chapter on knowledge production, isn't revising the usual syllabus precisely what Maria Bucur is asking us to do? With both of these books, Bucur is issuing a challenge to us all. She is inviting us to join her and use our knowledge of gender history to write more broadbased surveys for a general audience that ask different questions and take different priorities. And she is also asking us to reconsider the ways we teach and to dare to overturn student expectations by reorganizing our courses in radical ways. In other words, the audience for these books is for us to create.

\section{$\diamond$ About the Author}

Melissa Feinberg is Professor of History at Rutgers University, New Brunswick. She is the author of Curtain of Lies: The Battle over Truth in Stalinist Eastern Europe (Oxford: Oxford University Press, 2017) and Elusive Equality: Gender, Citizenship and the Limits of Democracy in Czechoslovakia, 1918-1950 (Pittsburgh: University of Pittsburgh Press, 2006). E-mail: mfeinberg@history.rutgers.edu 